\title{
COMPUTER TOOLS APPLIED TO ANALYSIS OF SOLAR WATER HEATERS
}

\section{LEANDRA ALTOÉ ${ }^{1}$, DELLY OLIVEIRA FILHO ${ }^{2}$, JOYCE C. CARLO ${ }^{3}$, PAULO MARCOS DE B. MONTEIRO ${ }^{4}$}

\begin{abstract}
The simulation programs are important tools to analyze the different energetic alternatives, including the use of renewable energy. The objective of this study was to analyze comparatively the different computer tools available for modeling of solar water heaters. Among the main simulation software of solar thermal systems, there are: RETScreen International, EnergyPlus, TRNSYS, SolDesigner, SolarPro, e T*SOL. Among the tools mentioned, only EnergyPlus and RETScreen International are free, but they allow obtaining interesting results when applied together. The first one has a detailed module of energy analysis of solar water heaters, while the second one provides an detailed economic feasibility study and an assessment of emissions of greenhouse gases. RETScreen International and EnergyPlus programs are aimed at a diverse audience, including designers, researchers and energy planners.
\end{abstract}

KEYWORDS: simulation, solar energy, water heating.

\section{FERRAMENTAS COMPUTACIONAIS APLICADAS À ANÁLISE DE AQUECEDORES SOLARES DE ÁGUA}

RESUMO: Os programas de simulação são importantes ferramentas para análise de diferentes alternativas energéticas, incluindo o uso de energias renováveis. O objetivo deste trabalho foi realizar uma análise comparativa das diferentes ferramentas computacionais disponíveis para modelagem de aquecedores solares de água. Entre os principais programas de simulação de sistemas solares térmicos estão: RETScreen International, EnergyPlus, TRNSYS, SolDesigner, SolarPro e $T^{*} S O L$. Entre as ferramentas citadas, apenas o EnergyPlus e o RETScreen International são livres, mas permitem a obtenção de resultados interessantes quando aplicadas em conjunto. O primeiro possui um módulo de análise energética detalhado de aquecedores solares de água, enquanto o segundo possibilita um estudo detalhado de viabilidade econômica e uma avaliação de emissões de gases de efeito estufa. Os programas EnergyPlus e RETScreen International são destinados a um público-alvo diverso, incluindo projetistas, pesquisadores e planejadores energéticos.

PALAVRAS-CHAVES: simulação, energia solar, aquecimento de água.

\section{INTRODUCTION}

The computer programs are important tools for analyzing buildings and systems integrated to the construction. Through simulation, it is possible to evaluate the thermal and energetic performance of buildings for different design alternatives, such as architectural design, building materials, lighting system, air conditioning system and the use of renewable energy. Moreover, one could estimate the energy consumption and costs in the building and the environmental impacts of its use (MENDES et al., 2005).

The first programs of modeling of energy systems have been created in developed countries, in the 1970s, a result of the evolution of computational tools and the need for analysis of alternative energy sources. The interest in investigating renewable sources arose mainly due to the oil crisis and the increase of environmental awareness (BERKELEY LAB, 2011).

\footnotetext{
${ }^{1}$ Ph.D.student, Departamento de Engenharia Agrícola, Universidade Federal de Viçosa, leandra.altoe@ufv.br.

${ }^{2}$ Prof., Ph.D., Departamento de Engenharia Agrícola, Universidade Federal de Viçosa, delly@ufv.br.

${ }^{3}$ Prof., D.Sc., Departamento de Arquitetura e Urbanismo, Universidade Federal de Viçosa, joycecarlo@ufv.br.

${ }^{4}$ Prof., D.Sc., Departamento de Engenharia de Controle e Automação, Universidade Federal de Ouro Preto, paulo@em.ufop.br.

Recebido pelo Conselho Editorial em: 31-5-2012

Aprovado pelo Conselho Editorial em: 1-4-2013
} 
Nowadays, the Department of Energy of the United States lists in an electronic site over 300 simulation programs for the assessment of energy efficiency measures and renewable energy use in buildings. A brief description of each program is provided, as well as additional information such as target audience, programming language, and the strong and weak points of the tools. Among the main simulation programs for the design and the energy analysis of solar systems of water heating, there are: RETScreen International, EnergyPlus, TRNSYS, SolDesigner and T*SOL (EERE, 2012).

The building simulation programs, including the simulation of energy systems, are still not very widespread among Brazilian professionals in engineering and architecture, the main reason appointed was the complexity of programs with consequent difficulty and delay in learning. Typically, simulation programs require a large number of input data, and multidisciplinary knowledge of the users (WESTPHAL \& LAMBERTS, 2005). In this context, with many programs of modeling of solar water heaters, the objective of this article was to conduct a comparative assessment of different computational tools available, focusing on their abilities and their target audience.

\section{COMPUTATIONAL TOOLS}

\section{RETScreen international}

The program RETScreen International is directed to the analysis of projects that exploit different renewable energy sources and energy efficiency measures. It was developed by the Natural Resources Department of Canada, with the support of an international network of industry experts and university researchers (HARDER \& GIBSON, 2011).

The tool makes it possible to conduct comparative analyses among the use of renewable and conventional energy sources. It has specific modules for wind power projects, small hydros, cogeneration, photovoltaic, photothermal systems, biomass heat production and heat pumps (MARKOVIC et al., 2011).

The program evaluates the energy production, the reduction of emissions of greenhouse gases and the economic viability of clean energy projects (JUN et al., 2011). It has a database of products and meteorological bases of 4,700 cities located in different countries. The weather files inserted in the program are the Typical Meteorological Year type (TMY), created by compiling data from terrestrial weather stations and satellite observations of the North American Space Agency (CTEC, 2005).

RETScreen International can be used to evaluate the use of solar water heaters for domestic, commercial and industrial applications. The energy efficiency of the systems is calculated by widespread F-chart method (BECKMAN et al., 1977). Economic analyses are performed by methods of classical financial mathematics, while the reduction of emissions of greenhouse gases is calculated using a methodology created by the developers of the program (CTEC, 2005). A flowchart of inputs/outputs of the energy module of RETScreen International for analyzing solar water heaters is shown in Figure 1.

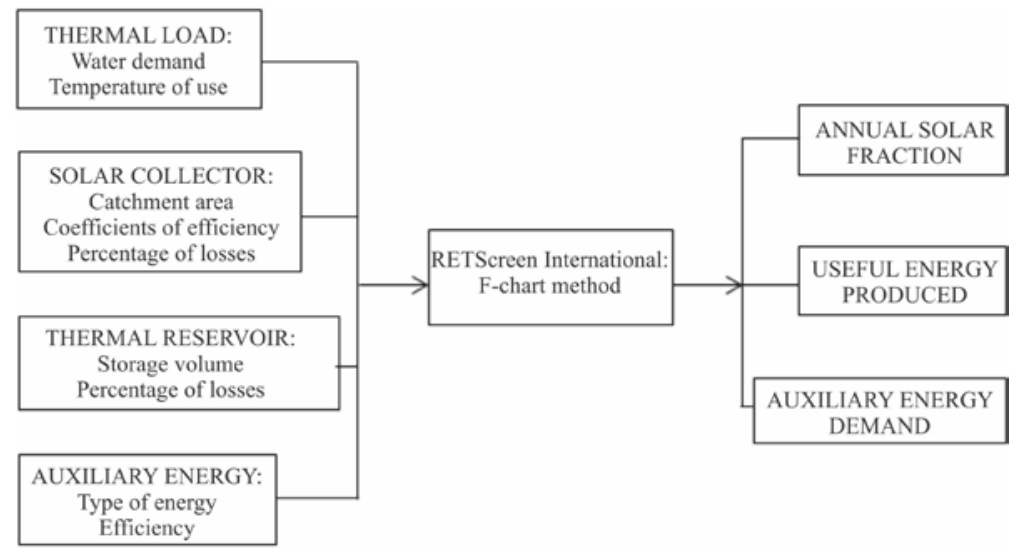

FIGURE 1. Flowchart of inputs and outputs of the energy module of solar water heaters of RETScreen International. 
The modeling is performed in a spreadsheet, in an intuitive way and easy for the user to understand (MENDES et al., 2011). The tool is available in over 30 languages today, including Portuguese. The Government of Canada maintains an electronic address with technical manuals, training courses and discussion forum for users of the program (NRCAN, 2012).

\section{EnergyPlus}

EnergyPlus program is currently one of the most frequently used computational tools to simulate the behavior of thermo-energy buildings. It was developed by the Department of Energy of the United States, through the merger of the BLAST and DOE-2 programs, and it includes new features (FUMO et al, 2010).

It was developed with the initial goal of enabling the calculation of heat exchange and energy consumption in buildings, through physical modeling of the construction and its systems. Seeking to meet new user requirements, the versions released since 2000 have additional features such as ability to add natural ventilation, thermal comfort indices, solar thermal and photovoltaic systems (CRAWLEY et al., 2001).

As RETScreen International, EnergyPlus calculates the energy efficiency of solar water heaters by the F-chart method and it works with the weather files of TMY type (BERKELEY LAB, 2011). The great difference between the energy modules of solar water heaters of both programs is the fact that EnergyPlus allows a more detailed analysis of the system, as can be seen in the flowchart of inputs/outputs shown in Figure 2.

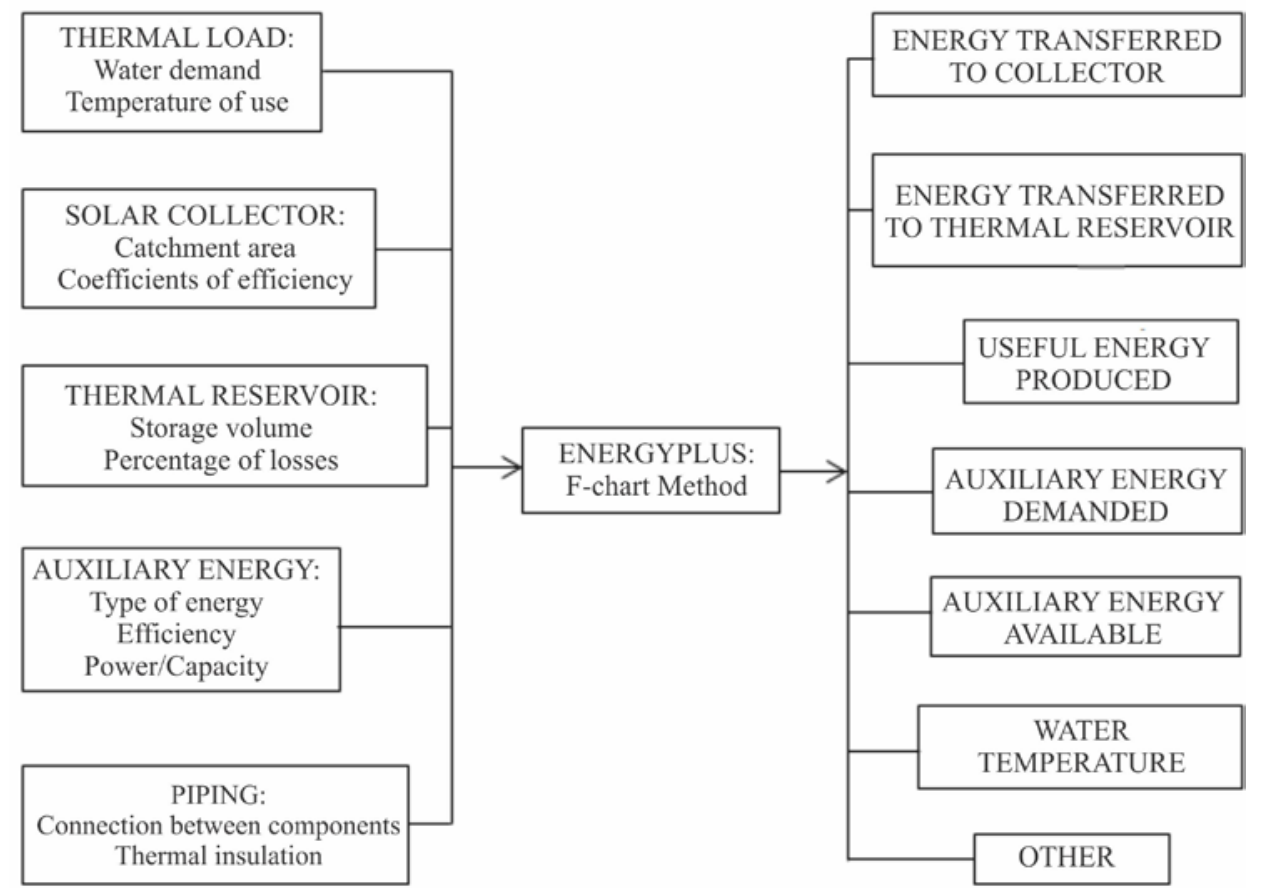

FIGURE 2. Flowchart of inputs and outputs of the energy module of solar water heaters of EnergyPlus.

The EnergyPlus has several features that put it ahead of other programs for modeling of buildings, such as: simultaneous and integrated simulation of different systems; simulation time interval shorter than one hour; calculation of transient heat; combination of heat and mass transfer and calculation of reduction of greenhouse gas emissions (CRAWLEY et al., 2001).

The program is structured in modules, which enables the user to develop each module without, necessarily, having the need of knowing all its features. Furthermore, this type of structure facilitates the continued development and incorporation of new features to the tool (SAILOR, 2008). 


\section{Other programs}

The TRNSYS is, currently, one of the most globally widespread photothermal system modeling programs. It was developed in the United States and its main advantage is performing transient analysis. Its modular nature allows great flexibility of simulation, allowing the insertion of mathematical models in the program. The library of TRNSYS has components and several routines that may be used by users of the programs (AYOMPE et al., 2011).

The SolDesigner program was developed in Germany and is intended primarily for design of systems of solar water heating, but it also can be used to make simplified energy analysis of the system. The simulation is performed based on geometric characteristics of the building, daily water heating demand and thermal load generating results as collector area, volume of thermal reservoir, estimates of energy production and costs avoided through the use of thermal solar energy (EERE , 2012).

Another German computational tool also widespread for modeling of solar heaters is the $\mathrm{T}^{*}$ SOL. Unlike SolDesigner, this tool allows the user to perform detailed thermal-energy analyses of the system. It features an extensive database containing specifications of solar collectors, thermal reservoirs, piping, hydraulic pumps and heat exchangers. Furthermore, it is possible to evaluate the economic viability of solar water heating projects (WOOLF, 2003).

The SolarPro program was developed in the United States, and, so as EnergyPlus, simulates the operation of solar water heaters at intervals using weather files of TMY type. The analyses are based on technical specifications of the system components and usage patterns of hot water. It features an intuitive simulation environment and allows the incorporation of user-defined parameters in the modeling (EERE, 2012).

\section{COMPARATIVE ANALYSIS OF COMPUTER TOOLS}

The EnergyPlus, RETScreen International, SolDesigner, SolarPro, TRNSYS and T*Sol tools have different capabilities; some are simple, with the main function of scaling, while others make a more detailed analysis of the system. There are also programs that allow to evaluate the economic viability and the potential for reducing greenhouse gases emissions. Table 1 presents a comparative analysis of such programs conducted by the Department of Energy of the United States.

TABLE 1. Comparative analysis of different programs applied to solar water heaters.

\begin{tabular}{|c|c|c|c|c|}
\hline Program & Strong Point & Weak Point & Target Audience & Access \\
\hline EnergyPlus & $\begin{array}{c}\text { Detailed and accurate } \\
\text { simulation, validated } \\
\text { by tests }\end{array}$ & $\begin{array}{l}\text { Data input in text } \\
\text { format can be more } \\
\text { troublesome }\end{array}$ & $\begin{array}{c}\text { Designers } \\
\text { Researchers } \\
\text { Consulting companies } \\
\text { Government agencies }\end{array}$ & Free \\
\hline $\begin{array}{l}\text { RETScreen } \\
\text { International }\end{array}$ & $\begin{array}{l}\text { Detailed economic } \\
\text { analysis }\end{array}$ & $\mathrm{n} / \mathrm{a}$ & $\begin{array}{l}\text { Designers } \\
\text { Planners } \\
\text { Managers } \\
\text { Educators }\end{array}$ & Free \\
\hline SolDesigner & $\begin{array}{l}\text { Water heating system's } \\
\text { design }\end{array}$ & $\begin{array}{l}\text { Does not calculate } \\
\text { the energy yield }\end{array}$ & $\begin{array}{c}\text { Designers } \\
\text { Constructors } \\
\text { Homeowners } \\
\text { Hydraulics specialists }\end{array}$ & Paid \\
\hline SolarPro & $\begin{array}{l}\text { Detailed modeling of } \\
\text { the solar heater }\end{array}$ & Complex input data & $\begin{array}{l}\text { Designers } \\
\text { Constructors } \\
\text { Homeowners }\end{array}$ & Paid \\
\hline TRNSYS & $\begin{array}{l}\text { Energy conversion } \\
\text { transient-modeling }\end{array}$ & $\begin{array}{l}\text { Does not have } \\
\text { standard input data }\end{array}$ & $\begin{array}{c}\text { Designers } \\
\text { Researchers } \\
\text { Consulting companies }\end{array}$ & Paid \\
\hline$T * S O L$ & $\begin{array}{c}\text { User friendly } \\
\text { simulation environment }\end{array}$ & $\mathrm{n} / \mathrm{a}$ & $\begin{array}{c}\text { Designers } \\
\text { Planners } \\
\text { Researchers } \\
\text { Educators }\end{array}$ & Paid \\
\hline
\end{tabular}


As shown in Table 1, some tools have simpler modules, which facilitates its use by students and homeowners who want to make a pre-sizing of a solar water heating system, as SolDesigner and T*SOL. Other tools allow detailed simulation of the system, which makes them applicable to scientific research, such as EnergyPlus and TRNSYS. There are those meant for different audiences due to various possibilities of analysis, such as RETScreen International.

In addition, the availability of the program (free or paid) is very important information for the user. Most computational tools presented in Table 1 is paid, however, EnergyPlus and RETScreen International programs, of open access have good options and meet different user profiles.

The analyses versatility of the RETScreen International, including calculation of energy production, economic feasibility study and the greenhouse gas emissions evaluation, has caused many users to opt for this program. According to a Canadian Government survey, in the period of 1998 to 2003, this tool was used in the design of projects in dozens of countries, including solar thermal, photovoltaic, wind, geothermal, biomass and small hydro. These projects had a total installed capacity of 342.1 MW of electricity generation and a area of 7,464 $\mathrm{m}^{2}$ of solar thermal collectors (CTEC, 2004).

Furthermore, this tool is widespread among energy planners and managers, as well among the scientific community, since many papers in the international literature employ the RETScreen International, including: solar thermal generation (GASTLI \& CHARABI, 2011), photovoltaic generation (HARDER \& GIBSON, 2011), wind plants (HIMRI et al., 2009) and small hydropower (ALONSO-TRISTÁN et al., 2011).

Unlike the RETScreen International, EnergyPlus has been predominantly used in scientific research due to its more complex and detailed simulation method. In the scientific literature, there are several studies using EnergyPlus for modeling of buildings and their systems, including: energy consumption (FUMO et al., 2010), energy performance (KIM \& PARK, 2011), HVAC systems (ZHOU et al., 2008), photothermal systems (BOJIC' et al., 2011), and photovoltaic systems (Wang et al., 2009).

\section{CONCLUSIONS}

Computational tools for the modeling of solar water heaters have been used, throughout the world, to assist professionals in tasks such as sizing and energy analyses. Nowadays, there is a wide variety of programs for different users. Amongst the most widespread tools, there are: RETScreen International, EnergyPlus, TRNSYS, SolDesigner, T*SOL and SolarPro.

Among the tools mentioned, only the EnergyPlus and RETScreen International are free, but allow obtaining interesting results when used together, and they are designed for a diverse audience, including designers, researchers and energy planners. The first program has a module of detailed energy analysis of solar water heaters, while the second one has modules of economic feasibility of the system and greenhouse gas emissions analysis.

Therefore, within the range of computer solar water heaters simulators currently available, it is necessary that the user know the tools specifications, such as programming language and capabilities so one may choose the program that is most suitable to produce the expected results for one's knowledge and modeling skills.

\section{ACKNOWLEDGEMENTS}

The authors thank Procel Edifica/Eletrobras, CNPq and FAPEMIG for their support to this research. 


\section{REFERENCES}

ALONSO-TRISTÁN, C.; GONZÁLEZ-PENA, D., DÍEZ-MEDIAVILLA, D.; RODRÍGUEZAMIGO, M.; GARCÍA-CALDERÓN, T. Small hydropower plants in Spain: A case study. Renewable and Sustainable Energy Reviews, Golden, v. 15, n. 6, p. 2729-2735, 2011.

AYOMPE, L. M; DUFFY, A.; MCCORMACK, S. J.; CONLON, M. Validated TRNSYS model for forced circulation solar water heating systems with flat plate and heat pipe evacuated tube collectors. Applied Thermal Engineering, Whitley Bay, v. 31, n. 8, p. 1536-1542, 2011.

BECKMAN, W. A.; KLEIN, S. A.; DUFFIE, J. A. Solar heating design by the F-chart method. Nova York: Wiley-Interscience, 1977. 218 p.

BERKELEY LAB - Lawrence Berkeley National Laboratory. Manual técnico: EnergyPlus. Orlando: Berkeley Lab, 2011. 1798 p.

BOJIC', M.; NIKOLIC', N.; NIKOLIC', D.; SKERLIC', J.; MILETIC', I. Toward a positive-netenergy residential building in Serbian conditions. Applied Energy, Stockholm, v. 88, n. 7, p. 24072419, 2011.

CRAWLEY, D. B.; LAWRIE, L. K.; WILKELMANN, F. C.; BUHL, W.F.; HUANG, Y. J.; PEDERSEN, C. O.; STRAND, R. K.; LIESEN, R. J.; FISHER, D. E.; WITTE, M. J.; GLAZER, J. EnergyPlus: creating a new-generation building energy simulation. Energy and Buildings, Oxford, v. 22, n. 4, p. 319-331, 2001.

CTEC - CANMET Energy Technology Centre. Manual técnico: RETScreen International. Varennes: CTEC, 2005. 108 p.

CTEC - CANMET Energy Technology Centre. RETScreen international: results and impacts 19962012. Varennes: CTEC, 2004. 44 p.

EERE - Office of Energy Efficiency and Renewable Energy. Building energy software tools directory. Disponível em: <http://apps1.eere.energy.gov/buildings/tools_directory/>. Acesso em: 20 fev. 2012.

FUMO, N.; MAGO, P.; LUCK, R. Methodology to estimate building energy consumption using EnergyPlus Benchmark Models. Energy and Buildings, Oxford, v. 42, n. 12, p. 2331-2337, 2010.

GASTLI, A.; CHARABI, Y. Solar water heating initiative in Oman energy saving and carbon credits. Renewable and Sustainable Energy Reviews, Golden, v. 15, n. 4, p. 1851-1856, 2011.

HARDER, E.; GIBSON, J. M. The costs and benefits of large-scale solar photovoltaic power production in Abu Dhabi, United Arab Emirates. Renewable Energy, Brighton, v. 36, n. 2, p. 789796, 2011.

HIMRI, Y; STAMBOULI, V.; DRAOUI, B. Prospects of wind farm development in Algeria. Desalination, Swansea, v. 239, n. 1, p. 130-138, 2009.

JUN, D.; XU, Z.; XUE, J; XIAOLIN, X; YUXI, T. Economic analysis and policy suggestions on gas power generation projects considering carbon emission reduction. Procedia Environmental Sciences, New York, v. 11, p. 1029-1038, 2011.

KIM, D.; PARK, C. Difficulties and limitations in performance simulation of a double skin façade with EnergyPlus. Energy and Buildings, Oxford, v. 43, n. 12, p. 3635-3645, 2011.

MARKOVIC, D; CVETKOVIC, D.; MASIC, B. Survey of software tools for energy efficiency in a community. Renewable and Sustainable Energy Reviews, Golden, v. 15, n. 9, p. 4897-4903, 2011.

MENDES, G; LOAKIMIDIS, C.; FERRÃO, P. On the planning and analysis of Integrated Community Energy Systems: A review and survey of available tools. Renewable and Sustainable Energy Reviews, Golden, v. 15, n. 9, p. 4836-4854, 2011. 
MENDES, N.; WESTPHAL F. S.; LAMBERTS R.; CUNHA NETO, J. A. B. Uso de instrumentos computacionais para análise do desempenho térmico e energético de edificações no Brasil. Ambiente Construído, Porto Alegre, v. 5, n. 4, p. 47-68, 2005.

NRCAN - Natural Resources Canada. RETScreen international. Disponível em: $<$ http://www.retscreen.net/pt/home.php>. Acesso em: 23 jan. 2012.

SAILOR, D. J. A green roof model for building energy simulation programs. Energy and Building, Oxford, v. 40, n. 8, p. 1466-1478, 2008.

WANG, L.; GWILLIAM, J.; JONES, P. Case study of zero energy house design in UK. Energy and Buildings, Oxford, v. 41, n.11, p. 1215-1222, 2009.

WESTPHAL, F. S.; LAMBERTS, R. Building Simulation Calibration Using Sensitivity Analysis. In: BUILDING SIMULATION, 9., 2005, Montreal. Proceedings... Montreal: IBPSA, 2005. p. 1331-1338.

WOOLF, J. Renew: a renewable energy design tool for architects. Renewable Energy, Brighton, v. 28, n. 10, p. 1555-1561, 2003.

ZHOU, Y. P.; WU, J. Y.; WANG, R. Z. SHIOCHI, S.; LI, Y. M. Simulation and experimental validation of the variable-refrigerant-volume (VRV) air-conditioning system in EnergyPlus. Energy and Buildings, Oxford, v. 40, n. 6, p. 1041-1047, 2008. 